\title{
Occupational exposures among healthcare workers: A teaching hospital sample
}

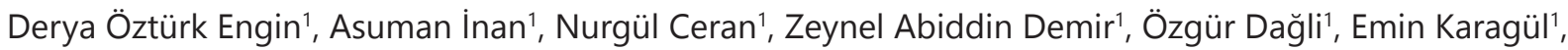 \\ Seyfi Özyürek ${ }^{1}$
}

Department of Infectious Diseases and Clinical Microbiology Haydarpaşa Teaching Hospital, İstanbul, Turkey

\begin{abstract}
Objective: Healthcare workers (HCWs) are at risk for occupational injury associated with contaminated blood and body fluids. This study aims to examine the frequency and type of occupational injuries and to determine best practices after exposure.
\end{abstract}

Methods: A cross-sectional study was conducted in Haydarpaşa Teaching Hospital in December 2010. The questionnaires were completed by healthcare workers with face-to-face interviews. The questionnaire was evaluated occupational injuries in the hospital practice.

Results: In total, 300of 350 healthcare practitioners (85.7\%) answered the questions; 125 (41.6\%) of them were nurses, $96(32.0 \%)$ were physicians, 36 (12.0\%) were cleaning staff, 23 (7.6\%) were student nurses, and 20 (6.6\%) were laboratory technicians. The number of HCWs who contact with blood and body fluids was 175 (58.3\%). Forty-five HCWs (15.0\%) have had injuries in the past year. The physicians had significantly lower injury rates $(p=0.004)$, while nurses had significantly higher $(p<0.001)$ injury rates.

Needle-stick injuries resulting in transmission of contaminated blood and body fluids occurred in 144 (82.2\%) HCWs. Among 175 injured HCWs, 54 (30.8\%) reported their injuries at the time of injury. Twenty-seven nurses (\%50) $(p=0.882)$, nine doctors $(16.6 \%)(p=0.126)$, eight cleaning staff $(14.8 \%)(p=0.448)$, seven laboratory technicians $(12.9 \%)(p=0.162)$, and three student nurses $(5.5 \%)(p=0.831)$ had reported their injuries.

Conclusion: Taking standard precautions against contact with contaminated blood and body fluid samples, reporting injuries, and not neglecting post-exposure prophylaxis may reduce risk of occupational exposure in HCWs. J Microbiol Infect Dis 2014;4(2): 64-68

Key words: Healthcare workers, occupational exposure, needle stick injury

\section{ÖZET}

\section{Sağlık çalışanlarında mesleki maruziyet: Bir eğitim hastanesi örneği}

Amaç: Sağlık çalışanları, kontamine kan ve vücut sıvıları ile mesleki yaralanma açısından risk altındadır. Bu çalışmanın amacı, mesleki yaralanmanın sıklığını, şeklini saptamak ve maruziyet sonrası uygulamaları belirlemektir.

Yöntemler: Haydarpaşa Eğitim Hastanesi'nde 2010 yılı Aralık ayında kesitsel bir çalışma yapıldı. Sağlık çalışanları ile yüz yüze görüşülerek anket formları dolduruldu. Ankette sağlık çalışanlarına hastane hizmetleri sırasında yaşadıkları mesleki yaralanmalar soruldu.

Bulgular: Anketin ulaştığı 350 sağlık çalışanından 300'ü $(\%$ 85,7) soruları yanıtladı. Sağlık personelinin 125'i $(\%$ 41,6) hemşire, 96'sı (\% 32,0) doktor, 36'sı (\% 12) temizlik personeli, 23'ü (\% 7,6) öğrenci hemşire, 20'si (\% 6,6) laboratuvar teknisyeni idi. Kan ve vücut sıvılarıyla maruziyet oranı 175 (\% 58,3) olarak belirlendi. Sağlık personelinin 45'inde $(\% 15,0)$ son bir yıl içerisinde yaralanma yaşadığını bildirdi. Sağlık personeli arasında kıyaslama yapıldığında; doktorlarda istatistiksel olarak anlamlı şekilde düşük $(p=0,004)$, hemşirelerde istatistiksel olarak anlamlı şekilde yüksek $(p<0,001)$ oranda yaralanma olduğu belirlendi. Kontamine kan ve vücut sıvılarıyla yaralanmanın 144 'ü $(\% 82,2)$ iğne batması idi. Yaralanma olan 175 sağlık çalışanından 54'ü $(\%$ 30,8) yaralanma olduğunu rapor etmişti. Hemşirelerin 27'si $(\% 50,0)(p=0,882)$, doktorların dokuzu $(\% 16,6)(p=0,126)$, temizlik personelinin sekizi $(\% 14,8)^{\prime} i(p=0,448)$, laboratuvar teknisyenlerinin yedisi $(\% 12,9)(p=0,162)$ ve öğrenci hemşirelerin üçü $(\% 5,5)(p=0,831)$ yaralanma olduğunu bildirmişti.

Sonuçlar: Standart temas önlemlerini uygulamak, yaralanma olduğunda bildirimi yapmak, maruziyet sonrası profilaksiyi yapmak sağlık personelinde mesleki maruziyet risklerini azaltabilir.

Anahtar kelimeler: Sağlık çalışanları, mesleki yaralanmalar, iğne batması

Correspondence: Derya Öztürk Engin, Department of Infectious Diseases and Clinical Microbiology Haydarpaşa Teaching

Hospital, Istanbul, Turkey Email: dr.deryaengin@gmail.com

Received: 22.03.2014, Accepted: 07.05.2014

Copyright (C) Journal of Microbiology and Infectious Diseases 2014, All rights reserved 


\section{INTRODUCTION}

Healthcare workers (HCWs) are at risk for penetrating injuries and contact with contaminated blood and body fluids. Such injuries are more likely to result in infections including hepatitis B virus (HBV), hepatitis $\mathrm{C}$ virus (HCV), and human immunodeficiency virus (HIV) that are transmitted via blood and might lead to serious or fatal consequences. Each year an average of three million percutaneous injuries are reported among 35 million HCWs around the world. ${ }^{1-3}$ The American National Institute for Occupational Health and Safety (NIOSH) has reported that $600,000-800,000$ needle-stick or other percutaneous injuries occur annually. ${ }^{1}$ The risk appears to be higher in developing countries due to higher rates of blood-borne infections.

Occupational contact occurs as a result of percutaneous (contact with needle and penetrating devices) or mucocutaneous injuries (contact with blood and other body fluids inside the eyes, mouth, and nose) or exposure to previously injured surfaces, blood, and other body fluids. The risk of infection varies based on the type and frequency of contact, amount of blood during contact, type and amount of virus in the blood, as well as the disease prevalence and the immunity of HCWs. ${ }^{4,5}$

This study aimed to determine the conditions that led to contact with contaminated blood and body fluids by HCWs and their practice after contact at Haydarpaşa Teaching Hospital through a questionnaire. It has been suggested that knowledge about occupational injury rates among $\mathrm{HCW}$ and identification of the causes may contribute to establishment of post-exposure medical practices as well as to reconsiderations of prevention and control precautions, and therefore reducing injury rates.

\section{METHODS}

The study was conducted at Haydarpaşa Teaching Hospital in December 2010. Standard prepared questionnaire forms were completed during faceto-face interviews with doctors, nurses, student nurses, cleaning staff, and laboratory technicians. Interviewees were asked whether they were exposed to contaminated blood and body fluids, type of exposure, reason for exposure, and department of exposure and post-exposure practices. Responses of HCWs to the questionnaire were entered into a computer database.

The NCSS 2007 software program was used for statistical analyses. Data were derived (mean, standard deviation, frequency distribution). The in- dependent t-test was used for paired comparisons and the chi-square test was used for comparison of qualitative data. A $p$ value of $<0.05$ was considered significant. The Ethics Committee of Haydarpaşa Teaching Hospital approved the study.

\section{RESULTS}

Haydarpaşa Teaching Hospital is a 750-beds hospital located in the center of Istanbul. In 2010 the staff of 2096 people was distributed as following: 623 (29.7\%) doctors, 488 (23.2\%) nurses, 413 (19.7\%) cleaning staff, $221(10.5 \%)$ information technology staff, 98 (4.6\%) lab technicians, $92(4.3 \%)$ cafeteria staff, $75(3.5 \%)$ security personnel, and $86(4.1 \%)$ other staff. In the same year, the total number of hospitalized patients was 30,540 , while the number of patients that received outpatient treatment was 95,348.

Among a total of $350 \mathrm{HCWs}$ that were interviewed, $300(85.7 \%)$ answered the questions. The mean age of interviewees was $30.3 \pm 7.2$ years (range 16-53 years). Two hundred of them were females $(66.6 \%)$ and 100 were males $(33.3 \%)$. The distribution of interviewees based on their profession was as following: $125(41.6 \%)$ nurses, 96 $(32 \%)$ physicians, $36(12.0 \%)$ cleaning staff, 23 (7.6\%) student nurses, and $20(6.6 \%)$ laboratory technicians. Blood and body fluids were present at the time of injury in $175(58.3 \%)$ of those interviewed. In the last year, $45 \mathrm{HCWs} \mathrm{(15 \% )} \mathrm{have} \mathrm{had}$ injuries induced by infectious materials. The most common type of injury in HCWs was found to be needle-stick injuries (Table 1).

Table 1. Characteristics of occupational contact with contaminated blood and body fluids

\begin{tabular}{ll}
\hline Types of occupational injuries & $\mathrm{n}(\%)$ \\
\hline Needle stick & $144(82.2)$ \\
Scalpels injury & $18(10.2)$ \\
Contact with the eye & $7(4.0)$ \\
Contact with mucosa of impaired integrity & $6(3.4)$ \\
Recapping needles & $100(57.1)$ \\
Intravenous access & $28(16.0)$ \\
During operation & $21(12.0)$ \\
Measuring blood glucose & $15(8.5)$ \\
While collecting garbage & $11(6.2)$ \\
Carelessness HCWs & $115(65.7)$ \\
Carelessness of Other HCWs & $54(30.8)$ \\
Work intensity & $3(1.7)$ \\
The urgency of the patient's condition & $3(1.7)$ \\
Total injured HCWs & $175(100)$ \\
\hline
\end{tabular}


The number of personnel injured during the recapping of the needle was $100(57.1 \%)$ and 64 $(64 \%)$ of them indicated that the needle should be recapped. Following exposure to injuries, the majority of healthcare workers illustrates $(69.7 \%)$ cleansed the injury site with soap and water (Table 2).

Table 2. The procedures of HCWs after injury

\begin{tabular}{ll}
\hline The procedure after injury & $\mathrm{n}(\%)$ \\
\hline Washing with soap and water & $122(69.7)$ \\
To do nothing & $41(23.4)$ \\
Wash with soap and water+ & $12(6.8)$ \\
antiseptic solution & \\
Prophylaxis after injury & $39(22.2)$ \\
\hline Tetanus vaccine & $36(20.5)$ \\
Hepatitis B vaccine & $8(4.5)$ \\
Hepatitis B immunoglobulin & $4(2.2)$ \\
Anti-retroviral prophylaxis & $175(100)$ \\
\hline Total injured HCWs &
\end{tabular}

Physicians had significantly lower injury rate $(p=0.004)$, while nurses had statistically significantly higher rates $(p=<0.001)$. When the departments were compared HCWs in the departments of internal disease had significantly lower rate of injury ( $p=0.017)$, although those in surgical departments and those in emergency room had statistically significantly higher rate of injury $(p=0.045)$ and $(p=0.043)$, respectively (Table 3$)$.

Table 3. The comparison of the groups with or without injury from contaminated blood and body fluids

\begin{tabular}{llll}
\hline Variables & $\begin{array}{l}\text { Non-expo- } \\
\text { sure } \mathrm{n}(\%)\end{array}$ & $\begin{array}{l}\text { Exposure } \\
\mathrm{n}(\%)\end{array}$ & $\mathrm{p}$ \\
\hline Gender (F) & $51(40.8)$ & $5(30.5)$ & 0.064 \\
Physician & $52(41.6)$ & $44(25.1)$ & 0.004 \\
Nurse & $36(28.8)$ & $89(50.9)$ & $<0.001$ \\
Cleaning staff & $17(13.6)$ & $19(10.9)$ & 0.589 \\
Nursing students & $13(10.4)$ & $10(5.7)$ & 0.199 \\
Laboratory technicians & $7(5.6)$ & $13(7.4)$ & 0.695 \\
Emergency department & $11(8.8)$ & $31(17.7)$ & 0.043 \\
Operating room & $3(2.4)$ & $31(5.7)$ & 0.243 \\
Hemodialysis & $4(3.2)$ & $11(6.3)$ & 0.347 \\
Internal medicine clinics & $70(56.0)$ & $59(33.7)$ & 0.002 \\
Surgery clinics & $23(18.4)$ & $41(23.4)$ & 0.045 \\
Intensive care unit & $14(11.2)$ & $23(13.1)$ & 0.744 \\
\hline
\end{tabular}

Among $175 \mathrm{HCW}$ s exposed to blood and body fluids, $54(30.8 \%)$ reported that they had sustained an injury. In 10 injuries where the source patient was hepatitis B virus antigen ( $\mathrm{HBs} \mathrm{Ag}$ ) positive, it was determined that all of injured staff had been vaccinated against hepatitis $B$. There were five injuries where the source patient was positive for antihepatitis $\mathrm{C}$ virus (anti-HCV) and four injuries where the source patient was positive for anti-HIV-positive; one of the source patients was determined to be both HIV and HCV positive. These injured HCWs reported their injuries and infection specialists did their follow-ups and treatments. We determined that 27 nurses $(50 \%)(p=0.882)$, nine doctors $(16.6 \%)$ $(p=0.126)$, eight cleaning staff $(14.8 \%)(p=0.448)$ seven laboratory technicians $(12.9 \%) \quad(p=0.162)$, and three nursing students $(5.5 \%)(p=0.831)$ had reported their injuries. The difference in terms of profession of reporting HCWs was not statistically significant. Among $121 \mathrm{HCWs}$ that did not report their injuries, $75(61.9 \%)$ indicated that they had thought there was little risk of transmission, while $46(38.0 \%)$ indicated that they had been busy.

Two hundred twenty-eight HCWs $(76 \%)$ had been vaccinated against hepatitis B. In nine (3.0\%) of them the vaccinations were being continued, two $(0.6 \%)$ had immunity, and three $(1.0 \%)$ were found to be carriers of hepatitis $B$.

When we evaluated all HCWs (those who reported their injuries and those who had not) in terms of source patients that they had been exposed to, we determined the following: 32 patients $(18.2 \%)$ were hepatitis B antigen positive, 15 (8.5\%) were anti-HCV positive and 4 (2.2\%) were anti-HIV positive. In injuries where the serology of the source patient was positive, no $\mathrm{HCW}$ s had $\mathrm{HBV}, \mathrm{HCV}$, and HIV transmission detected after contact.

\section{DISCUSSION}

The causative agents transmitted by blood constitute a serious occupational risk for HCWs. The transmission of these pathogens affects psychology as well as motivation of staff and is an economic burden. Injury rates throughout the careers of HCWs were reported to be $79.5 \%, 73 \%$, and $58 \%$ by Sharma et al., Kermode et al., and Karauzum et al., respectively. ${ }^{6-8}$ The injury rate was $58.3 \%$ in our study, similar to those reported in the literature. In all cases, the injury rates are high. Reduction in occupational injury is possible with the control and implementation of prevention methods. Hospitals must increase training and ensure continuity in training and safety 
measures regarding this subject. Behavioral changes acquired by training and the implementation of changes in the working-occupational-professional life will lower the rates of injury.

Injuries during needle re-capping and injuries while disposing waste are among the leading causes of needle-stick injuries, despite being preventable. ${ }^{8}$ In our study, $6.2 \%$ of occupational exposure happened during waste collection; among $100 \mathrm{HCWs}$ that were injured during re-capping the needle, 64 indicated that needle should be re-capped. Preventive procedures such as re-capping the injector needle after using or disposing the needle into medical waste are very simple, but when not implemented could harm personnel. Therefore, education, raising awareness, and inspection are essential.

The likelihood of contact with contaminated blood and body fluids varies from one to another department. ${ }^{2,9,10}$ Rele et al. reported that employees in surgical units have contact with contaminated blood and body fluids three times more often than employees from other departments. ${ }^{11}$ In our study we also determined that a significantly higher number of injuries occurred in the emergency room and surgery department, while there was a significantly lower number of injuries in the internal disease units. The higher the number of injuries caused by penetrating devices, the more frequent the interventional procedures and contact in surgical units. HCWs in surgical departments perform intervention more often and sometimes must perform procedures expeditiously due to severity of condition or high number of patients. However, our survey draws attention to the fact that carelessness of the staff makes up the leading cause of injury, rather than the urgency of the condition or the number of patients.

Another important problem is that HCWs often do not report occupational injury. O'Connor et al. determined that $53 \%$ of notifications were due to penetrating injuries. ${ }^{12}$ Haiduven et al. surveyed 549 individuals, $45 \%$ of whom said that they had no injury, $30 \%$ reported an injury, and $26 \%$ stated that they did not report their injuries. ${ }^{13}$ In the same study, the reasons for not reporting the injury were as following: HCWs thought that the injury was caused by a sterile instrument $(39 \%)$, the risk was low $(26 \%)$, they were too busy ( $9 \%)$, and they were discontent at follow-up (8\%). In our study, only $30,8 \%$ of healthcare providers reported their injuries. Nurses comprise the group who are most frequently exposed to occupational injury and report incidences. ${ }^{14,15}$ In case of injury, it is necessary to test the serology of the source patients and to implement the post- exposure prophylaxis in accordance with the immunity of the injured HCW. In our hospital, infection control nurses register penetrating injuries, and infectious diseases specialists assess injured HCWs and source patients. HCWs undergo prophylaxis and are followed-up, when needed.

Our country appears to be moderately endemic according to $\mathrm{HBsAg}$ seroprevalance, increasing the likelihood of exposure to HBV among HCWs in case of injury. ${ }^{16}$ Among HCWs, the rate of vaccination against $\mathrm{HBV}$ varies from $40-86 \% \cdot{ }^{17-19} \mathrm{As}$ a result of immunization practice carried out in our hospital, the rate of anti-HBs has been determined to be $76 \%$. Although medical staff has a high risk of encountering virus, it is possible to avoid HBV through post-exposure prophylaxis. For this reason, HCWs should be vaccinated against $\mathrm{HBV}$ at the beginning of their professional life before they start seeing patients.

There were a few limitations of our study. The equipment use during exposure and the length of spent time as a profession were not interrogated in our study. Transmission of the pathogenic microorganisms to HCWs is likely to occur through impaired mucosal integrity or eye. ${ }^{20}$ Standard precautions include wearing gloves as well as protective glasses and masks, taking account of a splash of the body fluids. Besides training, the length experience gained is of great importance in improving compliance with these measures. The clinical experience shows that it is possible to avoid exposure through simple measures.

In conclusion, every contact with contaminated blood and body fluids constitutes a risk for HCWs. In our study, more than half of HCWs had occupational exposure, and most of this exposure was determined to be needlestick. In order to reduce the risk of transmission of HBV, HCV, and HIV, medical staff should approach patients with caution, bearing in mind that the blood and body fluids might be contaminated, that they should not recapping needles, and that they should dispose of medical waste in accordance with the rules. In addition, all HCWs should be vaccinated against the HBV and report any injuries.

\section{REFERENCES}

1. National Institute for Occupational Safety and Health. NIOSH ALERT: Preventing needlestick injuries in health care setting DHHS (NIOSH) Publication No 2000-108. Nov 1999.

2. Hosoglu S, Akalin S, Sunbul M, et al; Occupational Infection Study Group. Healthcare workers' compliance with universal precautions in Turkey. Med Hypotheses 2011;77:1079-1082. 
3. Askarian M, Shaghaghian S, Gillen M. Assadian O. Body fluid exposure in nurses of Fars province, Southern Iran. Arch Iran Med 2008;11;515-521.

4. World Health Organization. Aide-memoire for a strategy to protect health workers from infection with bloodborne viruses. Geneva, Switzerland: WHO, November 2003.

5. Exposure to Blood. What Personel Need to Know. CDC booklet updated July 2003.

6. Sharma R, Rasania S, Verma A, Singh S. Study of prevalence and response to needle stick injuries among health care workers in a tertiary care hospital in Delhi, India. Indian J Community Med 2010;35:74-77.

7. Kermode M, Jolley D, Langkham B, et al. Occupational exposure to blood and risk of blood borne virus infection among health care workers in rural north Indian health care settings. Am J Infect Control 2005;33:34-41.

8. Karauzum Z, Elmali Z, Gunay S, et al. Occupational exposures to blood and body fluids among health care workers: a questionary survey. Mikrobiyol Bul 2008;42:61-69.

9. Galougahi MH. Evaluation of needle stick injuries among nurses of Khanevadeh Hospital in Tehran. Iran J Nurs Midwifery Res 2010;15:172-177.

10. Jagger J, Berguer R, Phillips EK, et al. Increase in sharps injuries in surgical settings versus nonsurgical settings after passage of national needlestick legislation. AORNJ 2011;93:322-330.

11. Rele B, Mathur M, Turbadkar D. Risk of needle stick injuries in health care workers-a report. Indian J Med Microbiol 2002;20:206-207.
12. O'Connor MB. Needlestick injury advice in the UK and Ireland. J Hosp Infect 2009:71:185-186.

13. Haiduven DJ, Simpkins SM, Phillips ES, Stevens DA. A survey of percutaneous/mucocutaneous injury reporting a public teaching hospital. J Hosp Infect 1999;41:151-154.

14. Husoy AM, Minde T, Knudsen H, Akselsen PE. Needlestick injuries and reporting routines. Tidsskr Nor Laegeforen 2010;8;130:735-737.

15. Hsieh WB, Chiu NC, Lee CM, Huang FY. Occupational blood and infectious body fluid exposures in a teaching hospital: a threeyear review. J Microbiol Immunol Infect 2006; 39:321-327.

16. Hepatitis $\mathrm{B}$. WHO department of communicable disease surveillance and response. WHO/CDS/CSR/LYO/2002.2.

17. Ziraba AK, Bwogi J, Namale A, et al. Sero-prevalence and risk factors for hepatitis $B$ virus infection among health care workers in a tertiary hospital in Uganda. BMC Infect Dis 2010;10:191.

18. Hadadi A, Afhami S, Karbakhsh M, Esmailpour N. Occupational exposure to body fluids among healthcare workers: a report from Iran. Singapore Med J 2008;49:492-496.

19. Celik Y, Akduman D, Kiran S. Evaluation of healthcare workers' and students' knowledge levels about infections transmitted by blood and body fluids, infection control measures, exposure frequencies and serological and hepatitis B vaccination status. Turkiye Klinikleri J Med Sci 2010;30:12461255.

20. Hosoglu S, Celen MK, Akalin S, et al. Transmission of hepatitis $\mathrm{C}$ by blood splash into conjunctiva in a nurse. Am J Infect Control 2003;31:502-504. 